\title{
The Role of Intellectual Image of the Commodity in Increasing Sales: A Case Study of Maestro Pizza Company
}

\author{
Somaia Osman Mohamed Abdelgadir ${ }^{1} \&$ Ahmed Osman Ibrahim Ahmed ${ }^{2}$ \\ ${ }^{1}$ Faculty of Economics and Administrative Sciences, Imam Muhammad Bin Saud Islamic University, Saudi \\ Arabia \\ ${ }^{2}$ Faculty of Applied Studies and Community Service, Imam Abdul Rahman Bin Faisal University, Saudi \\ Arabia \\ Correspondence: Ahmed Osman Ibrahim Ahmed, Faculty of Applied Studies and Community Service, Imam \\ Abdul Rahman Bin Faisal University, Saudi Arabia. E-mail: aoiahmed@iau.edu.sa
}

Received: November 28, 2017

Accepted: December 12, 2017 Online Published: December 20, 2017

doi:10.5539/ijbm.v13n1p277

URL: https://doi.org/10.5539/ijbm.v13n1p277

\begin{abstract}
The research dealt with the role of the intellectual image of the commodity in increasing sales, through the study of Maestro Pizza, as a local company with rapid growth and development. The main reasons for dealing with this issue were the study of the experience of this company and the reasons for its rapid success, although it is young in the market, and also in light of the great competition in the Saudi market. The main objectives of the research were to identify the factors affecting the intellectual image of consumers. The research was based on the analytical descriptive methodology, and its time limits were: 2013-2017 and in Riyadh, Saudi Arabia. The most important research hypotheses (the relationship between customer service and intellectual image of consumers). The study has reached to a number of findings, the most important of which are: Quality of service is one of the most important factors that create loyalty among consumers. A number of recommendations have been reached, including: the need to promote and develop the promotional activities of the company and to benefit from its ability to build a positive mental image.
\end{abstract}

Keywords: Intellectual Image, Increasing Sales, great competition

\section{Introduction}

In light of the openness of the world, and the dominance of the media and social networking sites, man has received thousands of different messages for many topics and many opinions, whether positive or negative, and communicates with different people, which enables him to form models. Negative or positive mental images of many things, people and companies as well, often ask why a person is famous while there is someone who is more worthy of such fame, or product fame while there are many products of higher quality, this is due to the ability of people or organizations In order to build a positive intellectual image in the minds of consumers ,and through many legitimate and illegal means as well, the research deals with the contribution of the intellectual image of consumers to the development of sales and also addresses the factors that affect the formation of intellectual image of consumers.

\subsection{Introduce the Problem}

It is nowadays easy to present opinions about the various products of a wide range in the light of technical progress and the direction of various websites, that enable consumers to put their views freely and discuss with a large number of people and influence their purchasing decisions , according to the experiences of others and solve problems quickly and show the extent of interest in the community and to multiply alternatives that may be used by others, so the company has to know the factors that affect the image negatively to address them and strengthen them that are the reason for drawing a positive intellectual image, towards the products, as any error may lead the organization to quickly extinction, The main research problem can be expressed in the following main question: To what extent did the positive intellectual image of consumers contribute to sales growth in Maestro Company? 


\subsection{State Hypotheses and Their Correspondence to Research Design}

The research was based on the following hypotheses:

1-There is a relationship between customer service and intellectual image of consumers.

2 -There is a relationship between the social responsibility of the company and positive intellectual image

3-There, is a relationship between the uses of social networking sites and good reputation of the company?

4-There is a relationship between promotional activities and the building of a positive mental image

\section{Method}

\subsection{Research Objectives}

1-To identify the factors affecting the intellectual image of consumers.

2-To identify the relationship between intellectual image and various promotional activities.

3- To learn to what extent the positive intellectual image has contributed to raising sales at Maestro.

4- To make recommendations and proposals that contributes to solving the problem of research.

\subsection{Research Methodology}

First: This research adopts descriptive analytical methodology, which describes the phenomena and events, specifically the case study methodology, and uses the statistical method to analyze data and information.

Second: Sources of data collection

Preliminary data: From the sample field of research using one of the most important data collection tools (questionnaire)

Secondary data: books and references, studies and research......

\subsection{Research limits}

Spatial: represented in the city of Riyadh

Temporal: from 2013 to $2017 \mathrm{~m}$

\subsection{Community and Sample of research}

Saudi Arabia - Riyadh, customers of Maistor Pizza Company in Riyadh with a population of 5,000,000. The sample size was 50 persons out of a total of 5,000,000. And this number, although it is small, but it can give an indicator helps to clarify the idea of research and solve the current

\section{Theoretical Framework}

\subsection{Marketing Concept}

In the face of increased competition, marketing is a real challenge for the organization to succeed, both in business organizations and public organizations. Marketing is the vital activity that ensures the survival, growth and prosperity of the organization.

Marketing is a structured and comprehensive activity that includes many integrated functions that are not limited to sales and promotion. They are much more comprehensive. The American Marketing Association has defined marketing as: "an organizational process that involves the planning, implementation and monitoring of well thought out activities, in the fields of formation, services through exchanges that serve the objectives of the organization and the individual (Zakaria, Abdel Basset, Mustafa 2015)

Stanton defined marketing as "an integrated business system that interacts with a range of activities designed to plan the production, delivery, pricing, promotion and distribution of goods in a desired manner by present and prospective consumers" (Mohammed, Hani, Shafig, 2014).(

\subsection{Marketing Development}

Marketing has passed through six stages until it reached what it has reached in our time. The following is some detail for each stage

1-The concept of production concept: This concept is based on the production of the largest possible quantity of goods required by consumers, as the consumer is willing to accept everything that can be produced (Muhammad 2008)

2-Product-related stage: It is an old concept that consumers respond positively to new products with a reasonable, single-price price. That is, the new product sells itself. The project needs a very limited marketing effort to 
achieve a profitable sales volume. (Zakaria, Abdel Basset, Mostafa 2015)

3-The Selling Concept Stage: This era began at the end of the First World War as competition grew and demand increased. There was a strong belief that consumers would only accept purchases if there was a tangible selling effort aimed at raising their interest in goods and services. (Mohammed 2005)

4-The concept of marketing: The concept of marketing is the latest idea in the history of exchange relations, which is an administrative approach where it is considered that the essence of the work of the organization is to identify the needs and desires of target markets (consumers) and to prepare the organization to achieve the desired satisfaction with the highest efficiency and effectiveness compared to competitors. (Zakaria, Abdel Basset, Mustafa 2015).

5-Social Marketing Stage: The idea of this concept is based on finding some kind of compatibility between social responsibility of the projects and the concept of modern marketing. The social role of marketing aims to provide the best life for the consumer by providing the appropriate goods and services, and avoiding pollution. (Mohammed 2005)

6/The ethical concept of marketing: It is an extension of the social concept of marketing, but it is more recent and comprehensive. It focuses on the different aspects of the social, ethical and customary responsibility of marketing as practice and application, as well as the behaviors and ethics of the practitioners of the marketing process and their ethics. Resulting from the provision of a service or commodity. (Zakaria, Abdel Basset, Mostafa 2015)

\subsection{Concept of Mental Image}

In its second edition, the Webster dictionary defines the intellectual image as "the mental presentation of anything that is not directly presented to the dialogue or is a simulation of a sensory experience associated with certain emotions and a retrieval of what memory has stored or represents the imagination of the five senses" (Ahmed 2013)

It is also a set of ideas, beliefs and feelings that are formed in the mind and consciousness of the public towards a cause, organization, idea or person it comes to mind when the name is mentioned to give a certain idea or a general concept that may be good or bad. (Ayman 2004)

\subsubsection{Nature of Mental Image}

Jeffkins believes that the concept of intellectual image is "linked to the right impression" and that the impression is true, if it is accurate information and may be incorrect if it is misleading or tendentious information, and emotions and psychological effects add another dimension in defining the features of the image, The information received by the individual and its perception in a manner inconsistent with the truth and the impact of previous preparations for individuals and trends related to what is perceived. (Ahmad 2003.)

3.3.2 Factors affecting the Process of Mental Image Formation: (Rifaat AlDabb 2014)

Personal factors:

1-Self-characteristics of the receiver of information (education, culture values).

2-Self-communication of the individual and his ability to absorb and interpret the information received and the formation of self-image features.

3- The degree of motivation of the individual and his interest in the information provided on the topics.

Social factors:

1-The influence of primary groups (family and friends) on the future individual of information.

2-The impact of the culture of society in which individuals and values prevail.

Media factors:

1-Media coverage of events in the mass media and the extent of their negative.

2-The importance of the mass media to the news on the subject.

\subsubsection{The Concept of Sale}

Selling is one of the important activities, since time immemorial which is important for the life of this world. There is not a day without going through the sale and purchase process. It has been mentioned in the Quran and the Sunnah in more than one place, such as saying: "Allaah has permitted selling and forbid usury", and the Prophet said "Gold is by gold, silver is by silver, barley is wild, bir by bir, dates by dates, and salt by salt, should 
be equal, for example, measured by hand, that who sold in more or more expensive, he used usury but if these species differed, sell how you like".

\subsubsection{Definition of Sale and Good for Selling}

The sale is a swap process with three parties sale, good and sold, while the sale is the subject of the contract or agreement and represents the mediator between the other parties, and the process

.Sales include a long list of activities such as ideas, services and goods. (Youssef Hamad 2008).

The sales department supervises the sales process. Sales department is defined as "the entity responsible for planning, executing and controlling the sales program designed to achieve the sales objectives of the organization and within the overall marketing strategy of the organization".

One of the tasks of the sales department is to manage the sales activity, and include the planning of the selling activity. It includes participation in the setting of goals and the establishment of sales policies within the organization, in addition to organizing the selling activity. This includes selling efforts through the development of an effective administrative and management structure for personal sales management, and many other tasks. (Mohammed, Hani, Shafig 2014).

Management is creating demands and opportunities that require adaptation and new approaches on the part of sales organization. The critical dimensions of change in the environment, affect practice of selling and sales management (Eli, Steven, Andris, Barton 2013).

The sales force effectiveness framework that organizes the complexities of sales organizations, providing a holistic approach to defining and assessing salesforce issues and develop multidimensional solutions either when responding to expand and internal events or when responding to external and internal events or when striving to improve.(Andris, Prabhakant, sally 2013).

\section{Case study of Maestro Pizza}

\subsection{Company Profile}

Established in 2013, Maestro Pizza is a Saudi company selling various types of pizza. Its products are characterized by high quality and diversity. It has achieved great success in a short period of time as it started to compete with international companies and led the prices of these companies and their sales increased significantly

\subsection{Methodological Procedures for the Study}

We address the methodological procedures that were followed in implementing the field study in terms of the objectives of the field study, the methodology used, the design of the study tool, the validity of the study, the application of the field study, and the statistical method used in analyzing the study data. The following offer

\subsection{Study Methodology}

In order to achieve the objectives of the study was adopted the descriptive survey methodology, which is based on the collection of facts and information and data to describe, analyze and interpret to derive findings.

\subsection{Study Tool}

After reviewing the literature and previous studies related to the subject of the study, the researchers designed a questionnaire on the role of mental images of the commodity in the development of sales figures to identify the views of the sample on the problem of study and treatment

Reliability and consistency of the questionnaire

Reliability of the questionnaire:

The questionnaire is designed to measure the validity of the questionnaire by measuring the apparent honesty of internal consistency as shown in the following table. 
Table 1. The correlation coefficient between the degree and the total score of each paragraph of the questionnaire and the total degree

\begin{tabular}{|c|c|}
\hline paragraph & correlation coefficient \\
\hline 1- Quality of service is an important factor in product selection. & $* 0.303$ \\
\hline 2-In case of low quality of the production for Maestro Pizza, it will resort to another alternative. & $0.417^{*}$ \\
\hline 3- Quality of service provided is an important factor in creating consumer loyalty & $* 0.341$ \\
\hline $\begin{array}{l}\text { 4- Taking care of current events in the community by Maestro Pizza creates a kind of preference for } \\
\text { its direction }\end{array}$ & $* 0.246$ \\
\hline $\begin{array}{l}\text { 5- Support by Pizza Maestro for a charity may contribute to improving the company's reputation } \\
\text { and covering some of its flaws }\end{array}$ & $* 0.169$ \\
\hline 6- Corporate news, especially rumors, is gaining popularity in social networking sites & 0.060 \\
\hline 7- We trust the opinions offered in social networking sites more than others & 0.076 \\
\hline $\begin{array}{l}\text { 8- The presence of Maestro Pizza in the social networking sites and constantly follow the views of } \\
\text { consumers and respond to them creates a kind of preference towards the company }\end{array}$ & $* 0.470$ \\
\hline $\begin{array}{l}\text { 9- Dependence on famous characters in promotion creates confidence in the direction of the } \\
\text { company's product }\end{array}$ & $* 0.311$ \\
\hline $\begin{array}{l}10 \text { Maestro Pizza's sponsorship of various events and programs gives an impression of the } \\
\text { company's activity and thus improves its reputation. }\end{array}$ & $* 0.301$ \\
\hline $\begin{array}{l}\text { 11- Give an opportunity to experiment with products and services before purchasing through free } \\
\text { samples increases the confidence towards the products of the organization }\end{array}$ & $* 0.0401$ \\
\hline 12- Repetition of advertisements significantly caused the demand to buy the product & $* 0.450$ \\
\hline 13 The positive mental image of a pizza maestro increases the demand to buy their products- & $* 0.502$ \\
\hline
\end{tabular}

*statistical indicator at significance level 0.05 .

It is clear from the previous table that the correlation coefficient values for each of the terms of the questionnaire are positive and statistically significant at the mean level of 0.01 and below, indicating that the terms of the questionnaire have a good degree of sincerity that can be relied upon in the study process, except for some that were not.

Structural honesty

Structural honesty is a measure of the validity of a tool that measures the extent to which the objectives the tool wants to achieve, and shows how closely each area of study relates to the overall score of the question paragraphs.

Table 2. Structural honesty of the questionnaire

\begin{tabular}{lll}
\hline Questionnaire & Number of paragraphs & Honesty \\
\hline Total grade & 13 & .0 .801 \\
\hline
\end{tabular}

Honesty $=$ positive square root for stability

It is clear from the results shown in Table (2-3) that the value of the accuracy of the questionnaire was $(0.801)$, which means that the questionnaire is very stable and honest

Stability of the questionnaire

The questionnaire is consistently intended to give the same result if the questionnaire is reapplied more than once under the same conditions and conditions.

The stability of the questionnaire

Was verified through the method of the Cranach's Alpha Coefficient as shown in Table (3-3)

Table 3. Calculation of the stability of the questionnaire using the alpha coefficient Cronbach

\begin{tabular}{lll}
\hline Axis & number of paragraphs & Coefficient of alpha Cronbach \\
\hline Total grade & 13 & 0.642 \\
\hline
\end{tabular}


From the previous table, the Alpha Kronbach coefficient for all axes (0.642), it is good. This great interest in the validity and consistency of the questionnaire is due primarily to the fact that the sample selected is fairly small and the researchers are keen that the results are the same if they were distributed to a larger number.

Procedures for using the study tool: The following steps were adopted in using the study tool

The questionnaire was based on the final form of (13) items. In order to answer the questions of the study, the arithmetic averages of thesample responses were used to indicate the degree of approval. The score was divided into 5 categories. As shown in the following table

Table 4. The five - dimensional Likert scale

\begin{tabular}{lll}
\hline Weight & opinion & $\begin{array}{l}\text { weight } \\
\text { Accepted }\end{array}$ \\
\hline 5 & Strongly agree & $4.20-5$ \\
4 & agree & $3.40-4.19$ \\
3 & Neutral & $2.60-3.39$ \\
2 & Disagree & $1.8-2.59$ \\
1 & Strongly disagree 1 & $1-1.79$ \\
\hline
\end{tabular}

\section{Results}

This chapter is consistent with the questions of the study. It includes a presentation and analysis of the results of the field study after applying the study tool to the selected sample, and processing the data statistically using the previous studies in commenting on the results.

Presentation of the characteristics of the study sample: The characteristics of the study sample were presented in the appendixes

Table 5. Responses of sample members on the intellectual image of the commodity in the evolution of sales figures

\begin{tabular}{|c|c|c|c|c|c|c|c|c|c|c|c|}
\hline $\mathrm{N}$ & Phrase & & $\begin{array}{l}\text { Strongly } \\
\text { Do not } \\
\text { agree }\end{array}$ & $\begin{array}{l}\text { Do } \\
\text { not } \\
\text { agree }\end{array}$ & Neutral & Agree & $\begin{array}{l}\text { Strongly } \\
\text { agree }\end{array}$ & $\begin{array}{l}\text { Arith. } \\
\text { Average }\end{array}$ & $\begin{array}{l}\text { Standard } \\
\text { Deviation }\end{array}$ & Relative.Wieght & Rank \\
\hline 1 & $\begin{array}{l}\text { "Quality of service is } \\
\text { an important factor for } \\
\text { product selection." I }\end{array}$ & $\begin{array}{l}\text { Q } \\
\%\end{array}$ & $\begin{array}{l}- \\
- \\
-\end{array}$ & $\begin{array}{l}1 \\
2.0\end{array}$ & $\begin{array}{l}- \\
-\end{array}$ & $\begin{array}{l}25 \\
50.0\end{array}$ & $\begin{array}{l}24 \\
48.0\end{array}$ & 4.44 & 0.61 & 88.8 & 2 \\
\hline 2 & $\begin{array}{l}\text { In case of worst } \\
\text { quality ,Maystro will } \\
\text { find } \\
\text { alternative. }\end{array}$ & $\begin{array}{l}\text { Q } \\
\%\end{array}$ & $\begin{array}{l}- \\
-\end{array}$ & $\begin{array}{l}1 \\
2.0\end{array}$ & $\begin{array}{l}5 \\
10.0\end{array}$ & $\begin{array}{l}26 \\
52.0\end{array}$ & $\begin{array}{l}18 \\
3.60\end{array}$ & 4.22 & 0.71 & 84.4 & 6 \\
\hline 3 & $\begin{array}{l}\text { "Quality of service } \\
\text { provided is one of the } \\
\text { important factors to } \\
\text { create consumer } \\
\text { loyalty" }\end{array}$ & $\begin{array}{l}\text { Q } \\
\%\end{array}$ & $\begin{array}{l}- \\
-\end{array}$ & - & $\begin{array}{l}1 \\
2.0\end{array}$ & $\begin{array}{l}21 \\
42.0\end{array}$ & $\begin{array}{l}28 \\
56.0\end{array}$ & 4.54 & 0.54 & 90.8 & 1 \\
\hline 4 & $\begin{array}{l}\text { Taking care of the } \\
\text { current events in } \\
\text { society by Maestro } \\
\text { Pizza creates a kind of } \\
\text { preference towards it" }\end{array}$ & $\begin{array}{l}\mathrm{Q} \\
\%\end{array}$ & $\begin{array}{l}- \\
-\end{array}$ & $\begin{array}{l}4 \\
8.0\end{array}$ & $\begin{array}{l}12 \\
24.0\end{array}$ & $\begin{array}{l}25 \\
50.0\end{array}$ & $\begin{array}{l}9 \\
18.0\end{array}$ & 3.78 & 0.84 & 75.6 & 8 \\
\hline 5 & $\begin{array}{l}\text { "The support of a pizza } \\
\text { maestro to a charity } \\
\text { may contribute to the } \\
\text { improvement of the } \\
\text { company's reputation } \\
\text { and cover some of its }\end{array}$ & & $\begin{array}{l}- \\
-\end{array}$ & $\begin{array}{l}5 \\
10.0\end{array}$ & $\begin{array}{l}17 \\
34.0\end{array}$ & $\begin{array}{l}19 \\
38.0\end{array}$ & $\begin{array}{l}9 \\
18.0\end{array}$ & 3.64 & .90 & 72.8 & 10 \\
\hline
\end{tabular}




\begin{tabular}{|c|c|c|c|c|c|c|c|c|c|c|c|}
\hline \multirow[b]{2}{*}{6} & shortcomings." & & & & & & & & & & \\
\hline & $\begin{array}{l}\text { ), "News about } \\
\text { companies, especially } \\
\text { rumors, is very popular } \\
\text { in social networking } \\
\text { sites.. }\end{array}$ & $\begin{array}{l}\text { Q } \\
\%\end{array}$ & - & $\begin{array}{l}2 \\
4.0\end{array}$ & $\begin{array}{l}6 \\
12.0\end{array}$ & $\begin{array}{l}23 \\
46.0\end{array}$ & $\begin{array}{l}19 \\
38.0\end{array}$ & 4.18 & 0.80 & 83.6 & 7 \\
\hline 7 & $\begin{array}{l}\text { The most trustworthy } \\
\text { opinions on social } \\
\text { networking sites" ca }\end{array}$ & $\begin{array}{l}\text { Q } \\
\%\end{array}$ & - & $\begin{array}{l}11 \\
22.0\end{array}$ & $\begin{array}{l}18 \\
36.0\end{array}$ & $\begin{array}{l}17 \\
34.0\end{array}$ & $\begin{array}{l}4 \\
8.0\end{array}$ & 3.28 & 0.90 & 65.6 & 11 \\
\hline 8 & $\begin{array}{l}\text { The presence of } \\
\text { Maestro Pizza in the } \\
\text { social networking sites } \\
\text { and the continuous } \\
\text { follow-up of } \\
\text { consumers' opinions } \\
\text { and the response to } \\
\text { them create a kind of } \\
\text { preference for the } \\
\text { direction of the } \\
\text { company". }\end{array}$ & $\begin{array}{l}\text { Q } \\
\%\end{array}$ & - & $\begin{array}{l}1 \\
2.0\end{array}$ & $\begin{array}{l}3 \\
6.0\end{array}$ & $\begin{array}{l}25 \\
50.0\end{array}$ & $\begin{array}{l}21 \\
42.0\end{array}$ & 4.32 & 0.68 & 86.4 & 5 \\
\hline 9 & $\begin{array}{l}\text { "relying on famous } \\
\text { personalities } \\
\text { promotion creates } \\
\text { confidence in the } \\
\text { direction of the } \\
\text { company's products." }\end{array}$ & $\begin{array}{l}\text { Q } \\
\%\end{array}$ & $\begin{array}{l}3 \\
6.0\end{array}$ & $\begin{array}{l}12 \\
24.0\end{array}$ & $\begin{array}{l}14 \\
28.0\end{array}$ & $\begin{array}{l}18 \\
36.0\end{array}$ & $\begin{array}{l}3 \\
6.0\end{array}$ & 3.12 & 1.04 & 62.4 & 12 \\
\hline 10 & $\begin{array}{l}\text { The care of Maystro } \\
\text { towards different } \\
\text { cultural activities gives } \\
\text { Maystro a good image. }\end{array}$ & $\begin{array}{l}\text { Q } \\
\%\end{array}$ & - & - & $\begin{array}{l}7 \\
14.0\end{array}$ & $\begin{array}{l}31 \\
62.0\end{array}$ & $\begin{array}{l}12 \\
24.0\end{array}$ & 4.10 & 0.61 & 82 & 7 \\
\hline 11 & $\begin{array}{l}\text { Giving an opportunity } \\
\text { to test products and } \\
\text { services before } \\
\text { purchasing through } \\
\text { free samples increases } \\
\text { confidence in the } \\
\text { direction of the } \\
\text { products of the } \\
\text { organization. }\end{array}$ & $\begin{array}{l}\text { Q } \\
\%\end{array}$ & - & - & $\begin{array}{l}3 \\
6.0\end{array}$ & $\begin{array}{l}23 \\
46.0\end{array}$ & $\begin{array}{l}24 \\
48.0\end{array}$ & 4.442 & 0.61 & 88.4 & 3 \\
\hline 12 & $\begin{array}{l}\text { "Repeated } \\
\text { advertisements with } \\
\text { great thanks to the } \\
\text { reason for the demand } \\
\text { to buy the product. }\end{array}$ & $\begin{array}{l}\text { Q } \\
\%\end{array}$ & $\begin{array}{l}1 \\
2.0\end{array}$ & $\begin{array}{l}1 \\
2.0\end{array}$ & $\begin{array}{l}9 \\
18.0\end{array}$ & $\begin{array}{l}22 \\
44.0\end{array}$ & $\begin{array}{l}12 \\
24.0\end{array}$ & 3.76 & 1.02 & 75.2 & 9 \\
\hline 13 & $\begin{array}{l}\text { The positive } \\
\text { intellecual image of } \\
\text { Maestro Pizza } \\
\text { increases the demand } \\
\text { for the purchase of } \\
\text { their products }\end{array}$ & $\begin{array}{l}\text { Q } \\
\%\end{array}$ & - & - & $\begin{array}{l}2 \\
4.0\end{array}$ & $\begin{array}{l}27 \\
540\end{array}$ & $\begin{array}{l}21 \\
42.0\end{array}$ & 4.38 & 0.57 & 87.6 & 4 \\
\hline & Mathematical Average & & & & & & & 4.01 & 0.76 & 80.3 & \\
\hline
\end{tabular}

It is clear from the previous table that respondents agree on the role of mental image of the commodity in the development of sales figures. The following are the terms of the questionnaire descending order according to the arithmetic averages 
-The phrase no. 3 "Quality of service provided is one of the important factors to create consumer loyalty", is the first with an average (4.45) of (5).

-The phrase (1), "Quality of service is an important factor for product selection." In second place with an average of (4.44) of (5).

-Phrase 11, "Giving an opportunity to test products and services before purchasing through free samples increases confidence in the direction of the products of the organization." In the third place with an average of (4.42) of (5).

"-Phrase 13The positive intellectual image of Maestro Pizza increases the demand for the purchase of their products." In the fourth place with an average of (4.38) from (5.)

"- Phrase 8 The presence of Maestro Pizza in the social networking sites and the continuous follow-up of consumers' opinions and the response to them create a kind of preference for the direction of the company."In fifth place with an average of (4.32) of (5).

--The phrase (6), "News about companies, especially rumors, is very popular in social networking sites." In seventh place with an average of (4.18) of (5).

--The phrase (4), "Taking care of the current events in society by Maestro Pizza creates a kind of preference towards it", ranked eighth with an average of (3.78) of (5).

-Phrase 12, "Repeated advertisements with great thanks to the reason for the demand to buy the product." Ranked ninth with an average of (3.76) of (5).

-Phrase 5, "The support of a pizza maestro to a charity may contribute to the improvement of the company's reputation and cover some of its shortcomings. "In the tenth place with an average of (3.64) of (5).

-The Phrase 7, "The most trustworthy opinions on social networking sites" came in 11th place with an average of (3.28) of (5).

-The phrase (9), "relying on famous personalities in promotion creates confidence in the direction of the company's products."In the 12th rank with an average of (3.12) of (5).

\section{Discussion}

First: Proof of the first hypothesis

To test the first hypothesis in the study, which states that "there is a relationship between customer service and intellectual image of consumers," the Pearson correlation coefficient was used to illustrate the strength of the relationship between the two variables.

Table 6. Relationship between customer service and intellectual image of consumers

\begin{tabular}{llllll}
\hline Axis & No. & $\begin{array}{l}\text { Arithmetic } \\
\text { mean }\end{array}$ & $\begin{array}{l}\text { Standard } \\
\text { deviation }\end{array}$ & $\begin{array}{l}\text { Pearson } \\
\text { correlation } \\
\text { coefficient }\end{array}$ & $\begin{array}{c}\text { Level } \\
\text { significance }\end{array}$ \\
\hline Customer Service & 50 & 4.40 & 0.442 & $0.385^{* *}$ & 0.00 \\
Intellectual image of consumers & 50 & 4.38 & 0.567 & \\
\hline
\end{tabular}

* Statistical function at a significant level 0.05 .

Table 5 shows that the correlation coefficient is 0.385 and the significance of 0.00 is less than 0.05 , which means that there is a correlation between the customer service and the mental image of the consumers. Therefore, the assumption that "there is a positive correlation is statistically significant between customer service and consumer image" is acceptable".

Second: Proof of the second hypothesis:

To test the second hypothesis in the study, which states: "There is a relationship between CSR and positive intellectual image," the Pearson correlation coefficient was used to illustrate the strength of the relationship between the two variables 
Table 7. Relationship between CSR and positive intellectual image

\begin{tabular}{llllll}
\hline Axis & No. & $\begin{array}{l}\text { Arithmetic } \\
\text { mean }\end{array}$ & $\begin{array}{l}\text { Standard } \\
\text { deviation }\end{array}$ & $\begin{array}{l}\text { Pearson } \\
\text { correlation } \\
\text { coefficient }\end{array}$ & $\begin{array}{l}\text { Level } \\
\text { significance }\end{array}$ \\
\hline $\begin{array}{l}\text { Corporate Social Responsibility } \\
\text { Positive intellectual image }\end{array}$ & 50 & 3.710 & 0.590 & 0.275 & 0.053 \\
\hline
\end{tabular}

* Statistical function at a significant level 0.05 .

Table 6 shows that the correlation coefficient was 0.275 and the significance of 0.053 , which is greater than 0.05 , which means that there is no correlation between CSR and the positive mental image. Therefore, the hypothesis that "there is a statistically significant correlation between corporate social responsibility and positive mental image" is refused.

Third: Proof of the third hypothesis

To test the third hypothesis in the study, which states: "There is a relationship between the use of social networking sites and good reputation of the company," Pearson correlation coefficient was used to illustrate the strength of the relationship between the two variables.

Table 8. Relationship between the use of social networking sites and the good reputation of the company

\begin{tabular}{llllll}
\hline Axis & No. & $\begin{array}{l}\text { Arithmetic } \\
\text { mean }\end{array}$ & $\begin{array}{l}\text { Standard } \\
\text { deviation }\end{array}$ & $\begin{array}{l}\text { Pearson } \\
\text { correlation } \\
\text { coefficient }\end{array}$ & $\begin{array}{l}\text { Level } \\
\text { significance }\end{array}$ \\
\hline Use of social networking sites & 50 & 927.3 & 0.505 & 0.028 & 0.874 \\
Good reputation of the company & 50 & 4.380 & 0.567 & \\
\hline
\end{tabular}

Statistical function at a significant level 0.05 .

Table 7 shows that the coefficient of correlation was 0.028 and the significance of 0.847 , which is greater than 0.05 , which means that there is no correlation between the use of social networking sites and the good reputation of the company. Therefore, the hypothesis that "there is a significant correlation Statistics between the use of social networking sites and good reputation of the company, is refused".

Fourth: Proof of the fourth hypothesis

To test the fourth hypothesis in the study, which states that "there is a relationship between promotional activities and the construction of a positive mental image, Pearson's correlation coefficient was used to illustrate the strength of the relationship between the two variables.

Table 8 . The correlation between promotional activities and the construction of positive intellectual image

\begin{tabular}{lcllll}
\hline Axis & No. & $\begin{array}{l}\text { Arithmetic } \\
\text { mean }\end{array}$ & $\begin{array}{l}\text { Standard } \\
\text { deviation }\end{array}$ & $\begin{array}{l}\text { Pearson } \\
\text { correlation } \\
\text { coefficient }\end{array}$ & $\begin{array}{l}\text { Level } \\
\text { significance }\end{array}$ \\
\hline Promotional activities & 50 & 3.850 & 0.522 & $* * 0.558$ & 0.00 \\
Building the positive intellectual image & 50 & 4.380 & 0.567 & \\
\hline
\end{tabular}

A statistical function at a significant level of 0.05 .

In Table 8 , it is clear that the correlation coefficient is 0.558 and the value of 0.00 is less than 0.05 which means that there is a correlation between the promotional activities and the building of the positive mental image. Therefore, the hypothesis that "there is a statistically significant correlation between Promotional activities and building a positive mental image is acceptable

\section{Findings and Recommendations of the Study}

The following are the main findings and conclusions of the study, in addition to presenting the most important recommendations and proposals. 
First, the findings and conclusions: The study reached the following findings

1-Quality of service is one of the most important factors that create the loyalty of consumers.

2-The findings of the study also indicate that there is no relationship between the use of social networking sites and the good reputation of the company.

3-Attention to social responsibility may not create a positive intellectual image of the organization in some cases.

4-The need to rely on the process of testing products and services before buying through free samples, increases consumer confidence towards the products of the company.

5-Positive intellectual image enhances the confidence of consumers and thus increase the demand for purchase.

6-Being near the client through social networking sites creates a kind of familiarity with the direction of the company.

7-The results of the research explained that clients will search for alternative products in the event of low quality provided, this alerts the need to pay attention to the quality of the product and service, as well as continue to monitor the preferences and tastes of consumers to the importance of this aspect in increasing sales and continue to grow and face competition.

8-The rumors of companies spread rapidly through social networking sites.

9-repeat ads one of the reasons for increased sales of Maestro Pizza.

Second: Recommendations:

The following are the main recommendations of the study:

1-Conduct training courses for employees in the company to develop the level of service, and provide rewards for outstanding employees in customer service.

2-Paying attention to the social responsibility of the company through supporting charities, recruiting and training Saudi youth or other forms of social responsibility, thus enhancing the intellectual image of the consumers as well as the relevant governmental bodies.

3-Increase interest in advertising in various forms and innovate new ones to keep pace with the market and face competitors.

4-Benefiting from the communication technology to reach customers and to know their desires and preferences and respond quickly to them through social networking sites.

5-Online Reputation Management is responsible for managing the company's reputation as a result of the spread of news and rumors in light of the development of communication technology.

6-The need to promote and develop promotional activities and to benefit from their ability to build a positive mental image.

7-The need to use reputable celebrities and good influence to ensure a positive image of the organization.

8-Interested in conducting further studies and researches regarding consumer tastes and preferences to increase the quality of the company's products

\section{Acknowledgments}

Thank God for helping us complete this research. And I thank all participants for answering the questionnaire.

\section{References}

Al Dabae, R. (2014). Star Produce. General Egyptian institute for book, Cairo.

Albakri, T. (2009). Marketing Communication and Promotion. Alhamid publishing and distribution house, Oman

Aldimor, H. ( 2005). Distribution channels Management. Wael Publishing house, Oman.

Alsairafi, M. (2005). Principles of Marketing. Moris international institute publishing house.

Altaei, H., \& Alalaag, B. (2008). Products pricing and development. Alyazori Publishing house, Oman.

Andris, A., Sinhat, Z., \& Lovimer, S. (2013). The sales force effectiveness. Northwestern University, United States of America.

Azam, A. A., Hasoona, A., \& Elshiekh, M. (2015). Principles of modern Marketing” between theory and practice”. Almasira publishing house, Aman. 
Eibaidat, M. (2014). Basics of Pricing in modern marketing “Behavioral Approach”. Almasira Publishing house, Oman.

Eibaidat, M. Aldimor, H., \& Hadad, S. H. (2014). Sales and Personal Selling. Wael publishing house, Oman.

Jones, E. Brown, P. Zoltners, A., \& Weitz, A. (2013). New developments and trends in Selling and Sales management. University of Hoston, United States of America.

Musa, A. A. (2003). Media War on Islam and Muslims. Zohor Almarifa and Albaraka Publishing house.

Nada, A. (2004). Intellectual and media image "factors and changes strategies". College of media Cairo university, Cairo.

Sulieman, Y. (2008). The Impact of Promotion on Sales Size. Omdurman Islamic University, Islamic world projects and studies institute, Omdurman.

\section{Copyrights}

Copyright for this article is retained by the author(s), with first publication rights granted to the journal.

This is an open-access article distributed under the terms and conditions of the Creative Commons Attribution license (http://creativecommons.org/licenses/by/4.0/). 